\title{
Działalność Komisji Epidemiologicznej Ligi Narodów w Warszawie 1921-1924
}

\begin{abstract}
Abstrakt: Celem artykułu jest analiza działalności Komisji Epidemiologicznej Ligi Narodów w Warszawie i próba odpowiedzi na pytania: jak kształtowały się jej stosunki z władzami polskimi, jakimi instrumentami dysponowała, jakie były efekty podejmowanych przez nią wysiłków? W oparciu o materiały z Archiwum Ligi Narodów w Genewie należy stwierdzić, że działalność placówki w Warszawie miała kluczowe znaczenie dla form działalności oraz rozwoju struktur organizacyjnych w ramach Ligi Narodów odpowiedzialnych za ochronę zdrowia. Ważną rolę w tym kontekście odegrał wybitny polski bakteriolog i działacz społeczny Ludwik Rajchman.
\end{abstract}

Słowa kluczowe: Liga Narodów, historia medycyny, walka z epidemiami, Ludwik Rajchman.

Abstract: The purpose of the article is to analyse the Epidemic Commission of the League of Nations' activity in Warsaw and answer the questions: how its relations with the Polish authorities developed, what instruments did it have at its disposal, and what were the results of its efforts? Based on the materials from the League of Nations Archives in Geneva, it should be said that the operation of the Commission in Warsaw was of key importance for the forms of activity and development of organisational structures of the League of Nations responsible for health protection. The outstanding Polish bacteriologist and social activist Ludwik Rajchman played a vital role in this context.

Keyw ords: League of Nations, history of medicine, fight against epidemics, Ludwik Rajchman. 
Kiedy powoływano do życia Ligę Narodów, jej architektom przyświecała przede wszystkim troska o zachowanie pokoju po wielkiej tragedii I wojny światowej ${ }^{1}$. Konflikty polityczne zdominowały obraz działalności Ligi, ale nie były to jedyne kwestie, którymi zajmowano się w Genewie. Wśród problemów, które znalazły się w kręgu zainteresowania urzędników Ligi Narodów, była m.in. ochrona zdrowia. W art. 23 paktu Ligi Narodów zapisano, że jej członkowie „poczynia starania celem podjęcia zarządzeń o charakterze międzynarodowym dla zapobiegania chorobom oraz ich zwalczania”. Na poczattku lat trzydziestych aktywność w tym zakresie urzędnicy Ligi wymieniali nawet wśród najważniejszych problemów, jakimi ta instytucja zajmowała się w pierwszej dekadzie swego istnienia ${ }^{2}$. Rzeczywiście w tej dziedzinie państwa europejskie były właściwie skazane na współpracę, mimo antagonizmów powstałych w wyniku Wielkiej Wojny oraz w efekcie późniejszych zmagań o granice. Liga Narodów miała ambicje, by spełniać tu ważną rolę koordynacyjna, chociaż nie była pierwszą organizacją międzynarodową podejmujacca działania na rzecz ochrony zdrowia. W pewnym zakresie zajmował się tym zagadnieniem Międzynarodowy Komitet Czerwonego Krzyża, chociaż po zakończeniu wojny powstała konkurencyjna Liga Towarzystw Czerwonego Krzyża bez udziału Austrii i Niemiec ${ }^{3}$. Od 1907 r. działał w Paryżu Międzynarodowy Urząd Higieny Publicznej (MUHP). Niemniej w Genewie uznano, że należy porozumieć się z pozostałymi organizacjami i połączyć siły w obliczu epidemii chorób zakaźnych rozprzestrzeniających się w Europie Wschodniej od $1919 \mathrm{r}$.

W dniach 13-20 IV 1920 r. Rada Ligi Narodów zwołała w Londynie konferencję międzynarodowa, by zastanowić się nad problemem epidemii tyfusu, duru powrotnego i cholery. Na konferencji, z udziałem delegacji polskiej w osobach szefa Państwowego Centralnego Zakładu Epidemiologicznego w Warszawie Ludwika Rajchmana oraz ministra zdrowia publicznego Witolda Chodźki, postanowiono powołać specjalną komisję epidemiologiczna, która koordynowałaby działania przeciw epidemii w Rosji, Polsce i krajach bałtyckich. Miała pomagać poszczególnym rządom, dostarczając im specjalistów, sprzęt szpitalny, a także odzież i żywność ${ }^{4}$. Podjęte działania oznaczały w istocie, że na granicy między Rosją a Polską planowano ustanowić kordon sanitarny, by zapobiec dalszemu rozprzestrzenianiu się chorób zakaźnych, do Europy Zachodniej. Rzeczywiście doniesienia z różnych źródeł były alarmujące, świadczyły o tym, że poziom epidemii w związku z masowymi migracjami ludności

\footnotetext{
${ }^{1}$ W języku polskim zob. syntezy: W. Balcerak, Liga Nadziei. Z dziejów Ligi Narodów, Warszawa 2010; S. Sierpowski, Liga Narodów w latach 1919-1926, Wrocław 2005; idem, Liga Narodów w najlepszym czasie (1926-1929), Poznań 2018.

${ }^{2}$ League of Nations. Ten Years of World Cooperation, Geneva 1930, s. 232.

${ }^{3}$ P. Weindling, Epidemics and Genocide in Eastern Europe, 1890-1945, Oxford 2011, s. 142.

${ }^{4}$ Ibidem.
} 
wzrastał od miesięcy ${ }^{5}$. Do tego dochodziły ruchy armii w związku z toczaca się wojna polsko-bolszewicka. Uczestnicy konferencji słusznie przewidywali, że po zakończeniu działań wojennych niebezpieczeństwo nie zniknie. Wręcz przeciwnie, repatrianci powracajacy z Rosji do Polski przynosili ze soba zagrożenie epidemiologiczne. Po latach szacowano, że epidemia tyfusu objęła 4 mln przypadków w Polsce i przynajmniej $25 \mathrm{mln}$ w Rosji (w tym 3-5 mln ofiar śmiertelnych) ${ }^{6}$. Nic dziwnego, że stolicę odrodzonej Polski wybrano na siedzibę biura Komisji Epidemiologicznej, jako swego rodzaju jej centrum operacyjne, a na jednego z jej członków wyznaczono wspomnianego Rajchmana.

Celem artykułu jest analiza instrumentów, jakimi dysponowała placówka Komisji Epidemiologicznej w Warszawie, kształt jej stosunków z władzami polskimi, efekty podejmowanych działań. Podstawę badania stanowia materiały zespołu Sekcji Zdrowia z Archiwum Ligi Narodów, częściowo wcześniej wykorzystane przez badaczy zainteresowanych działalnością Komisji Epidemiologicznej ${ }^{7}$.

$$
* * *
$$

Władze odrodzonej Polski były świadome znaczenia ochrony zdrowia obywateli i niebezpieczeństwa epidemii dla bytu narodu. Stąd mimo problemów finansowych państwa w pierwszych latach po odzyskaniu niepodległości działało odrębne Ministerstwo Zdrowia Publicznego (MZP). Jak słusznie zauważyła Elżbieta Więckowska: „Najważniejszym zadaniem MZP, podyktowanym chwilą dziejowa, było zwalczanie epidemii chorób zakaźnych, w tym szczególnie ostrych, grożących państwu klęską powszechną"8. Ramy prawne temu zadaniu nadała ustawa z 25 VII 1919 r., która m.in. wprowadziła obowiązek zgłaszania i rejestracji zachorowań na choroby zakaźne. Oczywiście uchwalenie ustawy i działalność scentralizowanego ministerstwa w warunkach toczacej się wojny nie rozwiązały problemu. Wciąż nie istniały na ziemiach polskich scalanych z trzech zaborów ani jednolita administracja służby

${ }^{5}$ Długoletni pracownik Sekretariatu Frank Walters w opracowaniu uważanym za oficjalna historię Ligi Narodów podkreślił, że „desperackie apele o pomoc dla Polski” były kierowane przez towarzystwa Czerwonego Krzyża. Zob. F.P. Walters, A History of the League of Nations, London 1952, s. 100.

${ }^{6}$ M.A. Balińska, Ludwik Rajchman. Życie w stużbie ludzkości, tłum. M. Braunstein, M. Krasicki, Warszawa 2012, s. 82; P. Weindling, op. cit., s. 154.

7 M.A. Balińska, Assistance and not mere relief: the Epidemic Commission of the League of Nations, 1920-1923, w: International Health Organisations and Movements, 1918-1939, red. P. Weindling, Cambridge 1995, s. 81-108; M.D. Dubin, The League of Nations Health Organisation, w: International Health Organisations and Movements..., s. 56-80.

${ }^{8}$ E. Więckowska, Walka z ostrymi chorobami zakaźnymi $w$ Polsce $w$ latach 1918-1924, Wrocław 1999, s. 33; zob. też: eadem, Kształtowanie się ochrony zdrowia, w: Dzieje medycyny $w$ Polsce. Opracowania i szkice, t. II: Lata 1914-1944, red. W. Noszczyk, J. Supady, Warszawa 2015, s. 66. 
zdrowia, ani zunifikowane prawo sanitarne. O trudności i wadze wyzwania świadczy decyzja MZP o powołaniu 1 VIII 1919 r. Centralnego Komitetu do walki z durem plamistym, w którego skład weszli przedstawiciele ministerstw, urzędów centralnych i zagranicznych misji sanitarnych. Po kilku miesiącach najwyraźniej uznano, że dotychczasowa organizacja ochrony zdrowia jest niewystarczająca, bo 28 II 1920 r. minister utworzył stanowisko Naczelnego Nadzwyczajnego Komisarza do walki z epidemiami, na które powołał profesora Wydziału Lekarskiego Uniwersytetu Jagiellońskiego - Emila Godlewskiego ${ }^{9}$. Od 31 VIII 1921 r. minister zdrowia publicznego Chodźko jednocześnie był szefem Naczelnego Nadzwyczajnego Komisariatu do walki z epidemiami (NNK), który pod jego wodzą wyszedł na czoło w zakresie zwalczania chorób zakaźnych. W czerwcu 1923 r., gdy Chodźkę odwołano, jego następca, Jerzy Bujalski również łączył swoją osobą stanowiska ministra i komisarza ${ }^{10}$.

$\mathrm{Na}$ najwyższym szczeblu podjęto decyzję o stworzeniu systemu kontroli repatriantów i powracajaccych do domu jeńców. W tym celu organizowano szpitale, punkty kapieli, dezynfekcji i dezynsekcji, miejsca szczepień i kwarantanny. Nie było to łatwe zadanie, wziąwszy pod uwage przynajmniej 1265000 osób, które system miał objac ${ }^{11}$. Ponadto na zrujnowanych wojna ziemiach polskich brakowało infrastruktury sanitarnej, środków czystości oraz świadomości mieszkańców, zwłaszcza wsi, o zagrożeniach. Władze polskie wiedziały o tych deficytach i rozpoczęły starania o pomoc za granica. Owocna okazała się współpraca z Misją Herberta Hoovera, Fundacją Rockefellera, narodowymi organizacjami Czerwonego Krzyża, Joint Distribution Committee $^{12}$. W organizowaniu pomocy medycznej władze polskie korzystały z kredytu na zakup leków w wysokości 100 tys. funtów szterlingów, udzielonego przez Ministerstwo Skarbu Wielkiej Brytanii w marcu 1919 r.

O szerzeniu się epidemii minister Chodźko alarmował społeczność międzynarodową już na konferencji dotyczącej tyfusu w Wiedniu, która odbyła się w dniach 15-16 IV 1919 r. Konferencja sanitarna w Londynie w kwietniu 1920 r. była kolejna, na której wystapili Chodźko i Rajchman. Następnie 28 kwietnia Chodźko przedstawił stan sanitarny Polski na posiedzeniu Komitetu MUHP w Paryżu, a 13 maja Rajchman wspólnie z Chodźka wystapili na posiedzeniu Rady Ligi Narodów. W rezultacie 19 maja Rada wezwała

${ }^{9}$ E. Więckowska, Walka z ostrymi chorobami..., s. 48. W oparciu o dokumentację Fundacji Rockefellera Paul Weindling dowodził, że utworzenie NNK było ustępstwem wobec „presji z zagranicy”, miało gwarantować podjęcie środków zaradczych. Według badacza dzięki Ludwikowi Rajchmanowi w Sekretariacie Ligi Narodów podjęto decyzję, aby środki finansowe przekazać bezpośrednio władzom polskim, a nie Lidze Towarzystw Czerwonych Krzyży. Zob. P. Weindling, op. cit., s. 144-145.

${ }^{10}$ E. Więckowska, Walka z ostrymi chorobami..., s. 58.

11 Ibidem, s. 60-62.

$12 \mathrm{O}$ początkach międzynarodowej akcji humanitarnej na ziemiach polskich zob. M.A. Balińska, Assistance and not mere relief..., s. 85. 
członków Ligi do przekazania 2 mln funtów na zwalczanie epidemii w Polsce, „która to sumę eksperci uznali za minimum potrzebne do poradzenia sobie z epidemia" ${ }^{3}$. Środki miały pochodzić z dobrowolnych składek poszczególnych państw. Wkrótce okazało się, że zbiórka jest nieskuteczna. Niemniej, gdy w październiku 1920 r. komisja Ligi Narodów zbadała potrzeby polskie na miejscu, apel o wsparcie ponowiono. Sprawę omawiano na I Zgromadzeniu Ogólnym Ligi Narodów. Właściwie nie pojawiały się sprzeciwy w tej sprawie, ale do sierpnia 1921 r. zebrano jedynie 126397 funtów. Krążyły opinie, że niebezpieczeństwo epidemii jest wyolbrzymiane tylko po to, aby usprawiedliwić akcję pomocy dla Polski ${ }^{14}$. Mimo nieosiagnięcia celu finansowego zbiórki mającej wspomóc walkę z chorobami zakaźnymi w Polsce, prace specjalnie powołanej w tym celu Komisji Epidemiologicznej winny być kontynuowane na miejscu. Na czele Komisji działającej w Warszawie 29 I 1921 r. ${ }^{15}$ staną Brytyjczyk Norman White, który już w 1920 r. dokonywał oględzin ognisk epidemii na obszarze Polski. W skład Komisji weszli: lekarz Francuskiej Misji Wojskowej płk Aimé Gauthier, Rajchman i mjr Fitzhugh reprezentujący Ligę Towarzystw Czerwonego Krzyża.

W lutym 1921 r. Rada Ligi Narodów podjęła decyzję, by utworzyć Komitet Doradczy Komisji Epidemiologicznej dla koordynowania działań podejmowanych przez Komisję, Międzynarodowy Urząd ds. Higieny Publicznej, Międzynarodowy Komitet Czerwonego Krzyża oraz Ligę Towarzystw Czerwonego Krzyża. Organizacje te wymieniono w rezolucji Zgromadzenia Ogólnego Ligi Narodów z 7 XII 1920 r. w sprawie zwalczania epidemii tyfusu w Polsce.

W dniach 15-16 IV 1921 r. w Warszawie odbyły się pierwsze posiedzenia Komitetu Doradczego Komisji Epidemiologicznej Ligi Narodów w Warszawie ${ }^{16}$. Oprócz czterech członków Komisji w zebraniu uczestniczyli: Dame Rachel Crowdy z Sekretariatu Ligi, Duńczyk prof. Thorvald Madsen kierujący Państwowym Instytutem Serologicznym w Kopenhadze, tu w roli reprezentanta MUHP, Szwajcarzy Frédéric Ferrière i Édouard Frick reprezentujący Międzynarodowy Komitet Czerwonego Krzyża, amerykański bakteriolog prof. Charles Winslow reprezentujący Ligę Towarzystw Czerwonego Krzyża oraz trzej przedstawiciele polskich władz: ówczesny minister zdrowia publicznego Chodźko, Godlewski kierujący NNK i komisarz epidemiologiczny na ziemie litewskie i białoruskie Czesław Wroczyński. Konferencji przysłuchiwali się również przedstawiciele różnych organizacji społecznych, do których wcześniej wystosowano zaproszenie.

${ }^{13}$ F.P. Walters, op. cit., s. 101.

${ }^{14}$ P. Weindling, op. cit., s. 147.

15 Taką datę, za polską dokumentacja, podaje: E. Więckowska, Walka z ostrymi chorobami..., s. 256.

${ }^{16}$ Biblioteka Narodów Zjednoczonych (Genewa), Archiwum Ligi Narodów, R822, Minutes of the first meeting of the Advisory Board of the League of Nations Epidemic Commission held in Warsaw, 15.04.1921. 
Norman White od razu poruszył kwestię finansowa, odnosząc się niejako do narzekań na niesatysfakcjonujące efekty zbiórki funduszy na walkę z chorobami zakaźnymi w Polsce. Największym donatorem okazała się Wielka Brytania, która przeznaczyła na ten cel 50 tys. funtów, następnie Grecja - 10 tys., Japonia - 5316 funtów, Szwecja - 3 tys. funtów, mniejszych wpłat dokonały też Persja, Belgia, Syjam, Finlandia, Peru, Austria, Bułgaria i Albania. Była także grupa innych krajów, które dopiero zapowiedziały rychłe wpłacenie sum. Następnie Godlewski przedstawił sprawozdanie z prac NNK, podkreślając, że wydatki państwa polskiego (nie tylko z budżetu NNK) osiagnęły kwotę 1,5 mld marek polskich (przyjmujac za pojawiajacym się kursem marki polskiej do funta, było to ok. 84 tys. funtów). W jego ocenie Komisja Epidemiologiczna Ligi Narodów włączyła się do walki z chorobami w Polsce w kulminacyjnym momencie tych zmagań. Jednak w części zamkniętej posiedzenia z podanych przez Wroczyńskiego liczb wynikało, że najgorszy okres już wówczas minął. Wskazał on bowiem, że w styczniu 1920 r. odnotowano 32 tys. zachorowań na tyfus, a rok później - 7 tys. (w dalszej części dyskusji dodał jednak, że brakuje statystyk z terenów wzdłuż granicy polsko-sowieckiej). Niemniej padła zapowiedź podjęcia kroków, które winny doprowadzić do całkowitego wygaszenia epidemii. Przede wszystkim miała zostać uszczelniona granica polsko-sowiecka, a ruch osobowy skoncentrowany w Baranowiczach i Równem. Wroczyński podkreślił znaczenie działania kolumn sanitarnych, które operując w promieniu 15-25 km, zwoziły chorych do szpitali, dezynfekowały domostwa oraz ludzi kontaktujących się z chorymi. Z 24 zaplanowanych szpitali na Kresach 10 już działało. Za najgroźniejszy Wroczyński uznał teraz dur powrotny, bowiem w pierwszym kwartale odnotowano ok. 3800 przypadków. Niemniej wciąż groźne były czerwonka oraz cholera. W drugim przypadku zastosowano metodę masowych szczepień (210 tys. osób) na obszarze najbliższym ognisku epidemii.

White wysoko ocenił działania instytucji polskich, występując niejako w roli recenzenta. Wyjaśnił uczestnikom obrad, że władze polskie udostępniły Komisji pomieszczenia należace do MZP (Warszawa, ul. Chocimska 2b) i umożliwiły inspekcje w terenie. Z kolei Godlewski podziękował za pomoc Komisji Epidemiologicznej, mówiąc, że to „pożądana współpraca wielu narodów w walce z epidemiami" ${ }^{17}$. Frick doceniając wysiłki komisarza, proponował wprowadzenie ścisłej kwarantanny na pograniczu wschodnim. Godlewski musiał wytłumaczyć realia: większość repatriantów przybywała koleja przez Równe i Baranowicze, tam kwarantanna była stosowana we wzorcowy sposób. Natomiast - jak objaśnił - „całkowite zamknięcie tak rozległej granicy było niemożliwe”. Później uspokajająco dodał, że „ruch ludności inaczej, niż koleja, jest stosunkowo nieznaczny”. Gauthier oceniał, że mimo spadku

${ }^{17}$ Ibidem, Minutes of the first meeting of the Advisory Board of the League of Nations Epidemic Commission held in Warsaw, 15.04.1921. 
zachorowań zagrożenie wciąż było duże, ponieważ kilkaset tysięcy ludzi nadal oczekiwało na repatriację do lub przez Polskę. White poruszając kwestię zakupu potrzebnych materiałów, podkreślił znaczenie zaangażowania ze strony Hamiltona i jego personelu w Londynie (chodzi tu prawdopodobnie o personel brytyjskiego Ministerstwa Zdrowia), „bez których praca byłaby prawie niemożliwa”. Dame Rachel Crowdy zaproponowała nawet formalne podziękowanie, co przyjęto jednomyślnie.

Rajchman stwierdził, że zaangażowanie Komisji Epidemiologicznej Ligi Narodów powinno się ograniczyć do zaplecza Baranowicz i Równego, czyli linii Grodno-Lida-Wilno-Białystok-Brześć i rozbudowy głównych stacji kwarantanny. Za pilne uznał dostawy butów i odzieży, za „wykonalne i ważne” wprowadzenie wstępnej kwarantanny w Moskwie. Frick zaproponował zwrócenie się z prośbą o środki finansowe do Fridtjofa Nansena kierującego akcja repatriacji jeńców wojennych. Godlewski podpowiedział nawet, że wśród repatriantów do i z Rosji były też grupy jeńców wojennych. Frick zwrócił natomiast uwagę na potrzebę izolacji obu tych grup żołnierzy od siebie. $\mathrm{Na}$ koniec Ferrière opowiedział się za otwarciem szkół dla pielęgniarek i ogólnie personelu służby zdrowia.

Od 15 do 21 IV 1921 r. Komitet dokonał inspekcji w szpitalach i stacjach kwarantanny w Warszawie, Baranowiczach, Lidzie, Wilnie, Oszmianie, Żołudku, Skidlu, Szczuczynie, Grodnie, Białymstoku i Sokółce. W raporcie sporządzonym na potrzeby Rady Ligi Narodów Crowdy zaznaczyła, że cały Komitet „był pod ogromnym wrażeniem (immensely struck) zdolności administracji obozu [przejściowego w Baranowiczach] i godnej podziwu pracy tam wykonywanej" ${ }^{18}$. Prace Komitetu podsumowano na zebraniu 22 kwietnia. W protokole podkreślono, że sytuacja w Polsce pod względem epidemiologicznym wciąż jest poważna. Co prawda, spadła znacząco liczba zachorowań na tyfus, ale i tak nadal była wielokrotnie wyższa niż przed I wojną światowa i nieporównanie wyższa od obszaru Europy Zachodniej. Dlatego należało wspierać Polskę, która „musi spełniać rolę bariery i zabezpieczenia Europy Zachodniej”. Zgodnie ze wcześniejszą opinią White'a bardzo wysoko oceniono wysiłki NNK w zwalczaniu chorób zakaźnych, widząc postępy jako „wynik odwagi i energii, zasługujących na podziw i wdzięczność świata”. Wydatkowanie środków uznano za mądre i bardzo efektywne. W porównaniu z nakładami władz polskich wsparcie ze strony Komisji Epidemiologicznej Ligi Narodów określono jako „stosunkowo niewielkie”, ale stanowiące „istotną wartość w dostawach odzieży, żywności, środków medycznych i transportu” ${ }^{19}$. Komitet wyznaczył sobie za cel dostarczenie pełnego wyposażenia dla 50 szpitali oraz

${ }^{18}$ Ibidem, Typhus - note by the Secretary-General (Report by Dame Rachel Crowdy), Genewa, 1.05.1921.

${ }^{19}$ Ibidem, Minutes of the first meeting of the Advisory Board of the League of Nations Epidemic Commission held in Warsaw, 15.04.1921. 
ubrań, żywności, medycznych środków transportowych ${ }^{20}$. W związku z tym Komitet postanowił również podjąć kolejna próbę zwiększenia budżetu na pomoc dla Polski i prosić sekretarza generalnego Erica Drummonda, by ponownie zaapelował do krajów, które już wcześniej zadeklarowały swoje wsparcie, by nie zwlekały z przekazywaniem środków finansowych. Drummond uznał jednak, że skoro dwa apele nie przyniosły skutku, to trzeci też raczej był skazany na fiasko. Dlatego 6 VI 1921 r. postanowił wystapić do Rady Ligi Narodów, by ta zastosowała „silny nacisk zarówno na własne jak i obce rządy, które nie wypełniły swoich obietnic, i przypomniała im wysokość kwot zadeklarowanych na rzecz Komisji Epidemiologicznej”"21. Otrzymanie tych funduszy kończył Drummond - miało umożliwić Komisji kontynuowanie prac w Polsce.

Postanowienia dotyczące dalszej pomocy dla Polski przyniosły też decyzje organizacyjne w ramach Ligi Narodów. W Genewie 22 VI 1921 r. Rada Ligi Narodów ustanowiła Tymczasowy Komitet Zdrowia oraz Sekcję Zdrowia - organ wykonawczy Sekretariatu Ligi Narodów. Na czele Sekcji stanął wskazany przez sekretarza generalnego Drummonda Rajchman. W Komitecie Zdrowia zasiadł natomiast Chodźko.

W dniach 25-29 VIII 1921 r. doszło w Genewie do serii posiedzeń Tymczasowego Komitetu Zdrowia. Brali w nich udział najwyżsi urzędnicy Ligi Narodów z sekretarzem generalnym Drummondem na czele oraz członkowie Komitetu: prof. Leon Bernard z uniwersytetu w Paryżu, George Buchanan z brytyjskiego Ministerstwa Zdrowia, H. Carrière ze szwajcarskiego Federalnego Departamentu Zdrowia, Chodźko, Alberto Lutrario z włoskiego Ministerstwa Spraw Wewnętrznych (MSW), Thorvald Madsen, prof. Miyajima z uniwersytetu w Tokio, Pulido - przewodniczący hiszpańskiej Królewskiej Rady Zdrowia Publicznego, M.O. Velghe - szef Departamentu Zdrowia belgijskiego MSW, F. Carozzi z Międzynarodowego Biura Pracy, prof. Winslow reprezentujący Ligę Towarzystw Czerwonego Krzyża i Rajchman ${ }^{22}$. Drummond na wstępie podkreślił, że państwa członkowskie przywiązują dużą wagę do wprowadzenia w życie art. 23 paktu, zakładającego walkę z epidemiami. Podsumował dotychczasowy dorobek Komitetu, wymieniajac Polskę jako miejsce udanej kampanii antytyfusowej. Rolę Komitetu i Rajchmana, którego mianował dyrektorem medycznym Ligi Narodów, widział w planowaniu działań i wypracowaniu metod współpracy z MUHP. Chodziło też o organizację szybkiej wymiany informacji między państwami oraz relacje między Komisja Epidemiologiczną i Komisją Opiumową. Następnie jednomyślnie wybrano Madsena na przewodniczącego Komitetu.

${ }^{20}$ Ibidem, Typhus - note by the Secretary-General (Report by Dame Rachel Crowdy), Genewa, 1.05.1921.

${ }^{21}$ Ibidem, Rapport du commissaire en chef sur la première réunion du Comité Consultatif de la Commission Épidémique (not du Secrétaire Général), 6.06.1921.

${ }^{22}$ Ibidem, R823, Minutes of the first meeting of Provisional Health Committee held in Geneva, 25-29.08.1921. 
W czasie jednego z posiedzeń poproszono White'a o przedstawienie sytuacji epidemiologicznej w Polsce i Rosji. Charakterystyczne, że White po krótkim wstępie (w którym zaznaczył, że sytuacja w Polsce została już opanowana) od razu oddał głos Rajchmanowi. Ten członek Komisji dokładnie wyjaśnił, na czym polegało stworzenie systemu ochrony przed chorobami zakaźnymi na pograniczu polsko-rosyjskim. Podkreślił, że właściwie nie wiadomo, co działo się po stronie rosyjskiej. Co ciekawe, odpowiadając na pytanie o skalę przemieszczeń ludności, stwierdził, że większość (the main body) repatriantów nie powracała do ojczyzny koleja, zatem trudno było całkowicie kontrolować ruch ludności. W przeciwieństwie do opinii, które usłyszał od reprezentantów polskiego NNK, nie bagatelizował ruchu transgranicznego odbywającego się inaczej, niż koleją, zatem poza wszelką kontrolą. Uważał, że repatriacja powinna się zakończyć w ciagu kolejnych 2-3 miesięcy. Winslow podkreślił, że wysiłek Komisji Epidemiologicznej był niewielki w porównaniu z praca wykonaną przez władze polskie. Natomiast White i Rajchman wnioskowali o wysłanie Komisji do Rosji, chociaż w Komitecie rodziły się wątpliwości, czy władze sowieckie zgodzą się na to. Sporo czasu poświęcono na dyskusje wokół podziału obowiązków między Komitetem Zdrowia i MUHP. Większość uczestników dyskusji opowiadała się za traktowaniem Urzędu jako ciała doradczego, a Komitetu jako instytucji wykonawczej. Przedmiotem dyskusji były również sposoby gromadzenia informacji o epidemiach. Rajchman ponownie wystapił w roli eksperta, mówiąc, że Liga Narodów powinna wyznaczyć osobę odpowiedzialną za opracowanie statystyki w oparciu o dane dostarczane przez poszczególne rządy.

Ważnym tematem ciagłych dyskusji między członkami Komisji Epidemiologicznej były problemy finansowe. Apele do rządów zawiodły. Dlatego środki finansowe próbowano pozyskać z innych źródeł. Frick napisał do Nansena z pytaniem, czy ten nie mógłby przekazać ze swoich funduszy kwoty 5 tys. funtów na zakup bielizny dla repatriowanych jeńców, którzy przechodzili kwarantannę w stacjach etapowych, na granicy polsko-sowieckiej, gdzie toczyła się walka z chorobami zakaźnymi. Nansen zasadniczo nie odmówił pomocy, ale wymienił szereg zastrzeżeń. Kwota ta absolutnie nie mogła być księgowana jako wydatki na walkę z tyfusem, bo fundusz Nansena był przeznaczony wyłącznie na repatriację jeńców wojny światowej. Nansen miał zatem wątpliwości, czy mógł przekazać te środki, bo przecież chodziło w tym wypadku o jeńców wojny polsko-bolszewickiej. Ostatecznie widział możliwość dofinansowania działań Komisji Epidemiologicznej, z zaznaczeniem, że „nie jest to darowizna, lecz pożyczka, przynajmniej formalnie” ${ }^{23}$. $\mathrm{Z}$ większym sceptycyzmem odnosił się do tego współpracujący z Nansenem T. Lodge, który napisał do Philipa Bakera w Genewie, że ma wątpliwości, czy dałoby się wykorzystać fundusze „jenieckie” na „tyfus”, zwłaszcza jeśli

${ }^{23}$ Ibidem, Pismo Fridtjofa Nansena do Fricka, Lysaker, 28.05.1921. 
byłyby to większe kwoty ${ }^{24}$. Wyglądało na to, że z funduszy przeznaczonych na wydatki związane z repatriacja jeńców wojennych została nadwyżka i można by ją spożytkować na walkę z tyfusem. Szukano natomiast formalnego sposobu, by środki przekazać na inny cel. Ostatecznie stwierdzono, że „pewna sumę" należy oddać do dyspozycji White'a w związku z jego inspekcjami obozów jenieckich w Polsce, uznając, że repatriacja jeńców oraz kampania antytyfusowa sa „bardzo ściśle ze sobą powiązane”. Na końcu swojego pisma skierowanego do Crowdy Baker dodał odręcznie, że „aprobata Dr. Nansena jest, rzecz jasna, warunkiem wstępnym" ${ }^{25}$. Ostatecznie chyba nie doszło do transferu środków.

Natomiast w sierpniu 1922 r. White zdziwiony napisał do płk. Gauthiera list, skarżąc się, że Gustaw Sztolcman z NNK oszacował koszt budowy szpitala zakaźnego (co miało zostać pokryte ze środków Komisji) na $620 \mathrm{mln}$ marek polskich. Według White’a nawet uwzględnienie deprecjacji polskiej waluty (27 tys. marek zamiast wcześniejszych 18 tys. marek za 1 funta) nie dawało podstaw do tak wysokiej sumy. Dlatego wyliczenia Sztolcmana były nie do przyjęcia dla delegata Ligi Narodów (szacującego całkowity koszt na 480 mln marek) ${ }^{26}$. Pracujacy dla Komisji urzędnicy starali się wydać otrzymywane środki jak najkorzystniej. Michał Birencwajg wykonujący różne zadania dla Komisji tłumaczył Rajchmanowi w listopadzie 1922 r.: „Baraki zimowe sa tak drogie żem nawet nie próbował pertraktować (cena 3 mil[iony] marek niem[ieckich]). Natomiast w razie potrzeby możnaby jeden kupić [i] fabrykować inne w kraju, gdyż tutaj drzewo tańsze. Szczegółowo napiszę w następnym liście"27.

Warto wspomnieć, że mimo stosunkowo skapych środków, jakimi dysponowała Komisja, doszło do niewielkiej (215,77 dolarów = 23250 marek polskich), ale cennej z punktu widzenia adresata dotacji na badania naukowe nad szczepionką przeciw tyfusowi, jakie prowadził dr Rudolf Weigl. Młody uczony w 1921 r. objął Katedrę Biologii Ogólnej Wydziału Lekarskiego Uniwersytetu Jana Kazimierza we Lwowie i tam kontynuował eksperymenty wszczepiania bakterii tyfusu wszom ${ }^{28}$. W lutym $1922 \mathrm{r}$. Weigl zwrócił się o pomoc finansową do Rajchmana, tłumaczac, że prowadził badania mające na celu wyprodukowanie skutecznej szczepionki przeciw tyfusowi plamistemu, zlecone przez Departament Sanitarny Ministerstwa Spraw Wojskowych. Pracownia była właśnie likwidowana, co praktycznie uniemożliwiało dalsze badania. „O ile więc nie otrzymam wybitnego poparcia dla ukończenia tych prac - tłumaczył Weigl - będę zmuszony pracę tę przerwać i zupełnie

\footnotetext{
${ }^{24}$ Ibidem, Pismo T. Lodge'a do Philipa Bakera, Paryż, 2.06.1921.

${ }_{25}$ Ibidem, Pismo Philipa Bakera do Rachel Crowdy, [b.m.], 23.05.1921.

${ }^{26}$ Ibidem, R822, Pismo Normana White’a do płk Gauthier, Genewa, 7.08.1922.

${ }^{27}$ Ibidem, Pismo Michała Birencwajga do Ludwika Rajchmana, Warszawa, 11.11.1922.

28 Szerzej zob. A. Allen, Fantastyczne laboratorium doktora Weigla. Lwowscy uczeni, tyfus i walka z Niemcami, tłum. B. Gadomska, Wołowiec 2016, s. 22-50.
} 
porzucić, gdyż nie mogę wydatkami koniecznymi dla wykończenia tych badań obciążyć budżetu mojej obecnej pracowni biologii ogólnej Uniw[ersytetu] Jana Kazim[ierza] we Lwowie. Cała zresztą dotacja zakładu nie pokryłaby i tak niezbędnych wydatków”29.

W czerwcu $1924 \mathrm{r}$. Weigl prosząc o dalsze finansowanie, proponował Rajchmanowi rozważenie zainicjowania programu opracowania standardowych metod badań nad tyfusem wśród szerszego grona bakteriologów ${ }^{30}$. Uważał, że najlepiej byłoby zorganizować konferencję naukowa albo przynajmniej przekonać czołowych badaczy do oddania swoich szczepów np. w ręce Komisji Epidemiologicznej. Weigl uważał to za dobry początek badań porównawczych, umożliwiający przekazywanie tych szczepów i surowic do dalszych pracowni bakteriologicznych. „Byłoby to - przekonywał Weigl - z punktu [widzenia] teoretycznego, zwłaszcza systematyki i całej biologii drobnoustrojów rzeczą niezmiernie doniosła, a dałoby być może i pewne wyniki praktyczne" ${ }^{31}$.

W dokumentacji dotyczącej działalności Komisji Epidemiologicznej pozostał też ślad po przekazaniu przez Rajchmana kolejnej kwoty - 500 funtów - na rzecz badań naukowych do MZP.

Z zachowanej korespondencji wynika, że w 1921 r. członkowie Komisji nawiazali kontakt z posłem sowieckim w Warszawie (by ta droga przekazać korespondencję do władz sowieckich w Moskwie) ${ }^{32}$, a potem zajęto się zakupem sprzętu medycznego przeznaczonego do wysyłki do Rosji i na Ukrainę. Za Frankiem Waltersem można podać, że we wrześniu Rajchman i White udali się do Moskwy na spotkanie z kierownictwem tamtejszego Komisariatu ds. Zdrowia i zapoczątkowali efektywną współpracę. Strona sowiecka udostępniła wiarygodne dane na temat epidemii na obszarze Rosji ${ }^{33}$. Dokładnie 6 grudnia odpowiedzialny za finanse Sekcji Zdrowia John Frederick Johnston-Watson potwierdzał wysłanie do Rosji pierwszego transportu ze szczepionkami, przy czym odbiorca był ludowy komisarz ochrony zdrowia Nikołaj Siemaszko ${ }^{34}$. Transporty miały być traktowane, jakby stanowiły część akcji humanitarnej Nansena ${ }^{35}$. W lutym 1922 r. do Mińska skierowano dziewięć

${ }^{29}$ Biblioteka Narodów Zjednoczonych (Genewa), Archiwum Ligi Narodów, R823, Pismo Rudolfa Weigla do Ludwika Rajchmana, Lwów, 10.02.1922.

${ }^{30}$ Ibidem, Pismo Rudolfa Weigla do Ludwika Rajchmana, Lwów, 6.06.1924.

31 Ibidem.

${ }^{32}$ Ibidem, R822, Pisma Ludwika Rajchmana do Johnstona-Watsona, Genewa, 3 i 7.11.1921. Rajchman instruował Watsona, że chciałby „poprzez poselstwo rosyjskie ustanowić kanał komunikacji z [Ludowym] Komisariatem [Ochrony] Zdrowia w Moskwie”. Dodał, że już mu obiecano dostarczanie wszelkich informacji na temat epidemii (3.11.1921).

${ }^{33}$ Raport prof. Tarasewicza został opublikowany w „Biuletynie Epidemiologicznym” Ligi Narodów w marcu 1922 r. Zob. F.P. Walters, op. cit., s. 102.

${ }^{34}$ Biblioteka Narodów Zjednoczonych (Genewa), Archiwum Ligi Narodów, R822, Pismo Johnstona-Watsona do Ludwika Rajchmana, Genewa, 6.12.1921.

${ }^{35}$ Ibidem, Pismo Johnstona-Watsona do Kantorowicza (Poselstwo Sowieckie), Warszawa, 25.11.1921. 
wagonów z żywnościa, odzieża, środkami czystości i lekami ${ }^{36}$. $\mathrm{Na}$ miejscu działał też wysłannik brytyjskiego Ministerstwa Zdrowia W.E. Haigh zajmujący się dystrybucją sprzętu medycznego i leków ${ }^{37}$. Do Rosji w imieniu Komisji jeździł Birencwajg i rozmawiał głównie z ludowym komisarzem ochrony zdrowia Siemaszką o współpracy, kontynuując niejako dyskusje prowadzone wcześniej w Moskwie przez Rajchmana i White'a. Z tej korespondencji można się zresztą dowiedzieć, że polska surowica była niestety znacznie gorszej jakości, niż pochodząca z Instytutu Pasteura w Paryżu. Ze sprawozdania Birencwajga wynika, że przy szczepieniach polska surowica stosowano podwójną dawkę ${ }^{38}$. Nie wpłynęło to na jakość współpracy ze strona sowiecka. Gdy w Genewie zapadła decyzja o zakupie w Niemczech leku Salwarsan, to właśnie Birencwajg prosił „o wyrażenie swego zdania”, bo uważał „za niesłuszne kupować niemiecki Salwarsan, płacić niesłychanie drogo [...] podczas gdy polski kosztuje niecałe $1000 \mathrm{mk}$ pol. ta sama ilość"39.

Rajchman i pracownicy Komisji w Warszawie angażowali się w polsko-sowieckie rozmowy w sprawie konwencji sanitarnej. Jak donosił do Genewy Birencwajg w grudniu 1921 r. (odsłaniając nieco kulisy negocjacji):

Dowiedziałem się nieoficjalnie [podkreślenie oryginalne - P.J.] trochę szczegółów w sprawie konwencji. Siemaszko zgodził się, choć twierdzi, że to więcej leży w interesie Polski oraz że takie zawarcie konwencji pozwoli $\mathrm{P}$ [olsce] zwalić winę na $\mathrm{R}$ [osję] za wszelkie zjawiska wynikajace $\mathrm{z}$ obecnego stanu repatriacji. Cziczerin jednak wobec zawarcia pokoju między P[olska] i R[osja] nie widzi potrzeby interwencji w tej sprawie Ligi Narodów. Siemaszko proponuje jako miejsce Moskwę. Korespondencja została przesłana do M[inisterstwa] S[praw] Zagr[anicznych] dla zakom[unikowania] MZP. Na razie nie mogę przesłać więcej danych, gdyż dopiero dzisiaj wieczorem mam otrzymać szczegóły. Telefonowałem do P[ana] Ministra czy otrzymał jakieś wiadomości od MSZ. Odpowiedź: nie! ${ }^{40}$

Johnston-Watson w liście z końca stycznia przedstawił sytuację nieco inaczej. Od jednego z urzędników sowieckich miał usłyszeć, że Gieorgij Cziczerin nie zaakceptuje oficjalnych przedstawicieli Ligi Narodów w Moskwie ze względu na sankcje polityczne, jakie z jej strony dotykały Rosję sowiecka. Natomiast nic nie stało na przeszkodzie, by pojawił się nieoficjalny przedstawiciel, by uczestniczyć w konferencji międzyrządowej ${ }^{41}$.

Współpraca z władzami sowieckimi nabrała szczególnego znaczenia od przełomu 1921 i 1922 r., ponieważ w regionie pogorszyła się sytuacja

${ }^{36}$ Ibidem, Pismo Johnstona-Watsona do Ludwika Rajchmana, Warszawa, 20.02.1922; zob. też: ibidem, Pisma Michała Birencwajga do Ludwika Rajchmana, Genewa, 30.11 oraz 4.01.1923.

${ }^{37}$ P. Weindling, op. cit., s. 167-168.

${ }_{38}$ Biblioteka Narodów Zjednoczonych (Genewa), Archiwum Ligi Narodów, R822, Pismo Michała Birencwajga do Ludwika Rajchmana, Moskwa, 9.07.1922.

${ }^{39}$ Ibidem, Pismo Michała Birencwajga do Ludwika Rajchmana, Moskwa, 20.12.1922.

${ }^{40}$ Ibidem, Pismo Michała Birencwajga do Ludwika Rajchmana, Warszawa, [b.d.; grudzień 1921].

${ }^{41}$ Ibidem, Pismo Johnstona-Watsona do Ludwika Rajchmana, Moskwa, 26.01.1922. 
epidemiczna. Z inicjatywy Rajchmana, pod auspicjami Ligi Narodów, władze polskie zwołały do Warszawy międzynarodową konferencję zdrowia, na która przybyli delegaci z 27 państw. Otwarta przez ministra spraw zagranicznych Konstantego Skirmunta 20 marca (trwająca do 28 marca) konferencja oznaczała przełom w walce z epidemiami. W jej wyniku doszło do współpracy międzynarodowej w zakresie zwalczania epidemii, a kluczowa była tu kooperacja polsko-sowiecka, chociaż Rajchmanowi udało się też pozyskać do współpracy niemieckich lekarzy. Musiał walczyć z ich uprzedzeniami do Ligi Narodów oraz niechęcią Francuzów, którzy nie chcieli słyszeć o wprowadzaniu Niemców do Sekcji Zdrowia Ligi. Niemniej już zgromadzenie tak szerokiej reprezentacji różnych państw władze odrodzonej Polski uważały za sukces ${ }^{42}$. Minister Chodźko zaznaczył to w przemówieniu kończącym obrady: „Stwierdzam z usprawiedliwioną dumą i radościa - panowie lekarze wszystkich krajów cywilizowanych, że właśnie dzięki nam nie tylko urzeczywistniło się gorące pragnienie Ligi Narodów zgromadzenia około jednego stołu przedstawicieli narodów niegdyś powaśnionych, lecz nadto dzięki nam [...] doszliśmy do powzięcia jednomyślnych postanowień, posiadajacych wielkie znaczenie dla przyszłości świata europejskiego". Chodźko podkreślił też rolę Ligi Narodów w całym przedsięwzięciu: „To właśnie Liga Narodów - stwierdził - natchnęła nas tym szlachetnym duchem i stworzyła atmosferę podniosłej godności moralnej, ułatwiając nam w ten sposób dojście do najzupełniejszej zgody" ${ }^{43}$.

W wyniku konferencji postanowiono rozszerzyć przepisy międzynarodowe dotyczące zwalczania chorób zakaźnych na dur plamisty, dur powrotny i ospę. Uproszczono system zgłaszania chorób zakaźnych i opracowano zarządzenia służące ograniczeniu zasięgu epidemii ${ }^{44}$. Padł też postulat zawarcia międzypaństwowych umów sanitarnych ${ }^{45}$. Sekcja Zdrowia Ligi Narodów miała pełnić rolę rozjemczą w sporach dotyczących spraw sanitarnych ${ }^{46}$.

Po konferencji warszawskiej widać było intensyfikację działań Komisji na terenie Rosji. W lipcu 1922 r. Birencwajg kończył jeden ze swoich listów

${ }^{42}$ Znaczenie konferencji w tym kontekście podkreślił w swoich wspomnieniach słynny bakteriolog i twórca polskiej szkoły immunologicznej Ludwik Hirszfeld: „Jako przedstawiciele państw przybyli zarówno szefowie Służby Zdrowia, jak i uczeni. Wszystkich uczonych zaprosiłem do siebie, przywiązując do tego wielkie znaczenie, gdyż była to pierwsza próba zespolenia na gruncie towarzyskim uczonych należących ongiś do wrogich obozów". L. Hirszfeld, Historia jednego życia, Kraków 2011, s. 116.

${ }^{43}$ Międzynarodowa konferencja sanitarna. Ostatnie posiedzenie, „Kurier Polski”, 29 III 1922.

${ }^{44}$ M.A. Balińska, Assistance and not mere relief..., s. 94-96. Umiarkowana ocena rezultatów konferencji u Weindlinga. Zob. P. Weindling, op. cit., s. 167-171.

${ }^{45}$ Polska w latach 1922-1923 zawarła konwencje sanitarne z Rosją sowiecka, odrębnie z republikami sowieckimi: ukraińską i białoruska, Rumunia, Czechosłowacja, Łotwą i Estonia. Z Niemcami została podpisana umowa o wymianie informacji o chorobach zakaźnych na pograniczu.

${ }^{46}$ M.A. Balińska, Ludwik Rajchman..., s. 101-104. 
do Rajchmana optymistycznie: „Nie sądzę, żeśmy przeszli Rubikon, ale mam wrażenie, że jesteśmy na twardym gruncie. Teraz należy tylko działać i jak najprędzej zobaczyć Pana Doktora w Moskwie"47. Genewie zależało na wciagnięciu władz sowieckich do dalszej, długofalowej współpracy. Birencwajg obiecywał nawet Siemaszce opłacenie kosztów podróży z Moskwy do Szwajcarii ${ }^{48}$. Tłumaczył się Rajchmanowi: „Obawiam się b[ardzo], że może zbyt daleko się posunąłem, ale ta sprawa obecne tak ważna, że sądzę, że P[an] Doktór znajdzie wyjście z tej sytuacji"49. W każdym razie w Moskwie i Charkowie zaczęły działać ekspozytury Komisji Epidemiologicznej Ligi Narodów. Zajmowały się zakupem i dystrybucją szczepionek przeciwko cholerze i dyzenterii ${ }^{50}$. W lutym 1923 r. z Warszawy wysłano do Rosji 300 łóżek $^{51}$. Przez biuro w Warszawie przechodziła też pomoc dla Grecji ${ }^{52}$. W grudniu 1922 r. Birencwajg wyjechał z transportem 13 skrzyń (ze szczepionkami) do rumuńskiego portu w Konstancy, by tam dopilnować załadunku przesyłki do Konstantynopola, z dalszym przeznaczeniem do Aten ${ }^{53}$. Jak wyjaśnił Rajchmanowi tę misję Johnston-Watson: „Wątpliwe, czy bez kuriera skrzynie w ogóle dotarłyby do miejsca przeznaczenia" ${ }^{54}$.

Chyba od początku działalności Komisji w Warszawie jej personel miał wątpliwości co do efektywności dystrybucji kupowanych materiałów. W grudniu 1921 r. Birencwajg widzac pełne magazyny Państwowego Zakładu Aprowizacji Sanitarnej (PZAS), zaraz napisał do Rajchmana: „Obuwie zakupione na samym początku leży w mag[azynie], to samo z ubraniem zakupionem przez JUR [Urząd ds. Powrotu Jeńców, Uchodźców i Robotników] - płaszcze, kurtki etc. Wszystko leży w mag[azynie] nietknięte. Bielizny francuskiej wysłano zaledwie nikła część, całe jedno piętro przepełnione tą bielizną"55. W maju 1922 r. Birencwajg ze zdziwieniem dowiedział się, że w związku z planem likwidacji PZAS duża część materiałów gromadzonych na rzecz walki z chorobami zakaźnymi (m.in. bielizna) miała zostać sprzedana.

${ }^{47}$ Biblioteka Narodów Zjednoczonych (Genewa), Archiwum Ligi Narodów, R822, Pismo Michała Birencwajga do Ludwika Rajchmana, Moskwa, 20.12.1922.

${ }^{48}$ Siemaszko uczestniczył w V sesji Komitetu Zdrowia Ligi Narodów w Genewie 11 I 1923 r. Wyraził wtedy zgodę na wymianę ekspertów medycznych oraz współpracę w zakresie propagowania higieny. Zob. P. Weindling, op. cit., s. 171.

${ }^{49}$ Biblioteka Narodów Zjednoczonych (Genewa), Archiwum Ligi Narodów, R822, Pismo Michała Birencwajga do Ludwika Rajchmana, Moskwa, 5.07.1922.

${ }^{50}$ Ibidem, Pismo Johnstona-Watsona do Ludwika Rajchmana, Warszawa, 20.06.1923.

${ }^{51}$ Ibidem, Pismo Johnstona-Watsona do Ludwika Rajchmana, Warszawa, 14.02.1923. O działalności Komisji w Rosji zob. też: M.A. Balińska, Assistance and not mere relief..., s. 96-99.

${ }^{52}$ Biblioteka Narodów Zjednoczonych (Genewa), Archiwum Ligi Narodów, R822, Pismo Johnstona-Watsona do Ludwika Rajchmana, Warszawa, 20.06.1923.

${ }_{53}$ Ibidem, Pismo Michała Birencwajga do Ludwika Rajchmana, Moskwa, 14.12.1922.

${ }^{54}$ Ibidem, Pismo Johnstona-Watsona do Ludwika Rajchmana, Warszawa, 11.11.1922.

55 Ibidem, Pismo Michała Birencwajga do Ludwika Rajchmana, Warszawa, [b.d.; grudzień 1921]. 
Nie mogę tego zrozumieć - pisał do Rajchmana - Motywy zaś podane zupełnie dzikie. Brak środków przewozowych. Czy nie uważałby Pan Doktor za stosowne interweniować w tej kwestii ze względu na dalsze zakupy dla Polski, nie poruszając już kwestii zasadniczej. Gdyby jednak P[an] Doktor zgodziłby się na tę sprzedaż - rozmyślał Birencwajg - to czy nie możnaby te rzeczy odkupić od Apr[owizacji] Sanit[arnej] w cenie kosztu [podkreślenie oryginalne - P.J.] dla Rosji? Uważam jednak, że sprzedaż bielizny (owych ang[ielskich] koszul, pan sobie przypomina zapewne te wielkie ilości tych koszul) jest niedopuszczalna choćby ze względu na pomoc L[igi] $\mathrm{N}$ [arodów] oraz potrzeb jakich wymagać będzie sprawa repatriacji ${ }^{56}$.

W maju 1923 r. Johnston-Watson zrobił objazd szpitali sfinansowanych przez Komisję. Najbardziej zaawansowana była budowa placówki w Brześciu, zaplanowanej na 60 łóżek. Kończono już tu trzy budynki - właściwy szpital, ambulatorium i mieszkanie dla personelu. Otwarcie szpitala miało się odbyć w lipcu 1923 r. W Małorycie było znacznie gorzej. Zabrakło pieniędzy na materiał budowlany, by kontynuować prace. Podobnie źle sytuacja wyglądała w Biłgoraju ${ }^{57}$. Strona polska usprawiedliwiała się „niesłychanym wzrostem cen robocizny i materiałów budowlanych". Nie pomagał nawet stosunkowo stabilny kurs funta, bo - jak tłumaczył Sztolcman w marcu 1923 r. - „w ciagu stycznia robocizna wzrosła o $52 \%$ a funt o $18 \%$, [i dlatego] wykończenie szpitali za sumę przyznaną [...] stało się niewykonalne" ${ }^{58}$. W każdym razie Komisja zaakceptowała plan koncentracji wydatków na szpitalach i łaźniach oraz zarezerwowania części środków na niespodziewane koszty związane z walka z epidemiami i repatriacja ${ }^{59}$.

Wyczerpanie funduszy spowodowało, że już w styczniu 1923 r. zaczęto dyskutować nad likwidacją Komisji Epidemiologicznej. Komitet Zdrowia pozostawiał jednak ostateczna decyzję polskiemu MZP z racji działania Komisji właśnie przy ministerstwie i w porozumieniu z nim ${ }^{60}$. Minister Chodźko próbował przekonać urzędników w Genewie, że działalność Komisji powinna być kontynuowana, bo choć sytuacja w Polsce ustabilizowała się, to w Rosji wciąż nie przejęto kontroli nad chorobami zakaźnymi i epidemie mogły jeszcze zagrozić Polsce i obszarom położonym na zachód od jej granic ${ }^{61}$. Jednak taka argumentacja dodatkowo wzmacniała przekonanie Rajchmana, by skoncentrować się na Rosji i tam przenieść główne centrum działań.

Pod koniec 1923 r. Johnston-Watson podsumował działania Komisji w Polsce, podkreślając w liście do White’a, że do 1 I 1924 r. wszystkie zaplanowane wcześniej szpitale zaczna funkcjonować (z wyjątkiem placówki w Biłgoraju, gdzie miejscowy samorząd nie był w stanie dopełnić inwestycji swoim wkładem

\footnotetext{
${ }^{56}$ Ibidem, Pismo Michała Birencwajga do Ludwika Rajchmana, Warszawa, 20.05.1922.

${ }^{57}$ Ibidem, Pismo Johnstona-Watsona do Normana White'a, Warszawa, 24.05.1923.

${ }^{58}$ Ibidem, Pismo Sztolcmana do Komisji Epidemiologicznej Ligi Narodów, Warszawa, 3.03.1923.

${ }^{59}$ Ibidem, Pismo Johnstona-Watsona do Ludwika Rajchmana, Genewa, 20.02.1923.

${ }^{60}$ Ibidem, Pismo Ludwika Rajchmana do Witolda Chodźki, Genewa, 15.01.1923.

${ }^{61}$ Ibidem, Pismo Witolda Chodźki do Ludwika Rajchmana, Genewa, 16.01.1923.
} 
finansowym) ${ }^{62}$. White 31 grudnia zapowiedział swoją krótką wizytę w Warszawie najpierw 10 lub 11 stycznia w trakcie podróży na konferencję do Moskwy, następnie ok. 20 stycznia w drodze powrotnej. Wtedy zamierzał dokonać „smutnego obowiązku zamknięcia biura Komisji Epidemiologicznej w Warszawie" ${ }^{63} .24$ stycznia Norman wysłał do premiera Władysława Grabskiego pismo, w którym stwierdził, że epidemie już „na szczęście” Polsce nie zagrażały, zatem praca Komisji Epidemiologicznej Ligi Narodów w Warszawie dobiegła końca i jej biuro wkrótce miało zostać zamknięte. Wyraził stronie polskiej podziękowanie za współpracę, zwłaszcza Ministerstwu Zdrowia Publicznego kierowanemu przez Chodźkę. Wskazał 11 szpitali wybudowanych i w pełni wyposażonych przez Komisję na potrzeby walki z epidemiami. Widział w tych placówkach trwały dorobek pracy Komisji, bo szpitale mogły być później użytkowane jako zwykłe placówki zdrowia. Tymczasem Wroczyński uważał, że Komisja powinna utrzymać swoje przedstawicielstwo. White w liście do Rajchmana pisał jeszcze 25 II 1924 r.: „Nie sądzę, byśmy mogli utrzymywać dłużej biuro, ale jeśli zaistniałaby prawdziwa potrzeba, to osobiście nie mam nic przeciwko, by Johnston-Watson pozostał na kolejny miesiacc" ${ }^{64}$. Zreszta likwidacja placówki Komisji Epidemiologicznej w Warszawie zbiegła się z rozwiązaniem zarówno odrębnego MZP oraz $\mathrm{NNK}^{65}$. W sumie wysokość subsydiów Ligi Narodów, które Komisja zużytkowała w Polsce, wynosiła 187424 funty.

Doświadczenia z Polski i Rosji z pewnością wpłynęły na dalsze ustalenia organizacyjne organów wykonawczych i doradczych Ligi Narodów. Członkowie Komitetu Zdrowia wspólnie z delegatami Komitetu Stałego MUHP przyjęli w maju 1923 r. plan zwalczania epidemii, zaakceptowany na IV Zgromadzeniu Ligi Narodów we wrześniu 1923 r. Ustanowiono Organizację Zdrowia złożoną z Komitetu Zdrowia (20 specjalistów w dziedzinie medycyny lub urzędników odpowiedzialnych za kwestie zdrowotności, spotykających się dwa razy w roku, pochodzących z różnych krajów, ale formalnie niereprezentujących swych rządów), Rady Doradczej wyznaczonej przez Komitet Stały MUHP oraz Sekcji Zdrowia - organu wykonawczego Sekretariatu Ligi Narodów. Chodziło o to, by działalność w zakresie zwalczania epidemii nie miała konotacji politycznych. I chociaż firmowała ją Liga Narodów, to jednym z członków Komitetu Zdrowia był szef amerykańskiej Federalnej Służby Zdrowia, czyli kraju nienależącego do Ligi. Komitet spełniał rolę swego rodzaju superdoradcy, przygotowując plan działań dla Sekcji Zdrowia oraz proponując szczegółowe rozwiązania dla idei wychodzacych z Rady Ligi Narodów bądź Zgromadzenia Ogólnego.

${ }^{62}$ Ibidem, Pismo Johnstona-Watsona do Normana White'a, Warszawa, 30.11.1923.

${ }^{63}$ Ibidem, Pismo Normana White'a do Jana Adamskiego (Ministerstwo Zdrowia Publicznego), Genewa, 31.12.1923.

${ }^{64}$ Ibidem, Pismo Normana White'a do Ludwika Rajchmana, Genewa, 25.02.1924.

${ }^{65}$ Okoliczności szczegółowo podaje: E. Więckowska, Walka z ostrymi chorobami..., s. 58-59, 257 (tu też data 1 II 1924 r. jako formalny moment likwidacji biura Komisji Epidemiologicznej w Warszawie). 
W Sekcji Zdrowia było zatrudnionych kilkunastu specjalistów - epidemiologów i statystyków, zbierających informacje z różnych krajów, dokonujących podróży studyjnych, przygotowujących konferencje i publikacje dotyczące problemów zdrowotności. Generalnie Organizacja Zdrowia zatrudniała wielu specjalistów, którzy opracowywali materiały naukowe, by na wyższym szczeblu podejmowano decyzje w mniej lub bardziej ważnych sprawach technicznych. Przyjęto ogólną zasadę, że prowadzone badania będą miały wymiar wyłącznie praktyczny, a działania - charakter międzynarodowy.

$$
* * *
$$

Komisja Epidemiologiczna, która zaczęła działać w Polsce, stanowiła przykład swego rodzaju poligonu doświadczalnego dla nowo powstałej Ligi Narodów w kwestii ochrony zdrowia na skalę europejską. Bezpośrednim efektem było wsparcie finansowe walki z epidemiami (choć sami funkcjonariusze Ligi Narodów przyznawali, że główny wysiłek spadł na władze polskie). Ponadto chodziło o zebranie rzetelnych informacji na temat przebiegu epidemii na pograniczu polsko-sowieckim ${ }^{66}$. W Genewie ustanowiono Epidemiologiczną Służbę Wywiadowcza, która regularnie publikowała szczegółowe raporty o chorobach zakaźnych w różnych częściach świata, w szczególności w Rosji i Polsce. Stopniowo rozszerzano liczbę krajów poddanych badaniom statystycznych i rodzaj chorób uwzględnianych w tabelach. Od lipca $1923 \mathrm{r}$. Sekcja Zdrowia publikowała raporty w cyklu miesięcznym. Następnie ogłaszano też raporty roczne. Urzędnicy w Genewie chcieli dostarczać rządom poszczególnych państw informacji o sytuacji u sąsiadów ${ }^{67}$. Stopniowo rosła świadomość potrzeby ujednolicenia metod zbierania i opracowywania informacji oraz potrzeby koordynacji działań prozdrowotnych. W miarę upływu czasu osiagnięto standaryzację kryteriów stosowanych przy gromadzeniu danych ${ }^{68}$. Chodziło też o znalezienie odpowiedniej formuły organizacyjnej, która połączyłaby wysiłki specjalistów z państw członkowskich Ligi oraz ekspertów pochodzacych ze Stanów Zjednoczonych, Niemiec, ZSRR. Nie można było także ignorować ambicji dotychczasowych organizacji ds. zdrowia, chcących uniknąc wtopienia w struktury Ligi Narodów.

7 I 1924 r. Rajchman jako dyrektor medyczny przedstawił raport dotyczący działalności Organizacji Zdrowia Ligi Narodów między czerwcem 1923 a styczniem 1924, czyli ostatniego okresu funkcjonowania Komisji Epidemiologicznej w Warszawie ${ }^{69}$. Raport został odczytany przed IV Zgromadzeniem

${ }^{66}$ Ibidem.

${ }^{67}$ Ibidem, s. 236. O standaryzacji surowic i szczepionek zapoczątkowanej przez Ligę Narodów oraz inicjowaniu prac zespołów międzynarodowych zob. L. Hirszfeld, op. cit., s. 116-117.

${ }^{68}$ Ibidem, s. 240.

${ }^{69}$ Biblioteka Narodów Zjednoczonych (Genewa), Archiwum Ligi Narodów, R822, Report of the medical director on the general activities of the Health Organization from June 1923 until January 1924, Geneva, 7.01.1924. 
Ligi Narodów. Wcześniej Rada zwróciła się do Zgromadzenia o zaakceptowanie planu działań zaproponowanego przez komisję mieszaną Organizacji Zdrowia. Zgromadzenie plan zaaprobowało, akcentując potrzebę ścisłej współpracy z MUHP, co świadczy, że te tarcia były nadal widoczne i dochodziło do sporów kompetencyjnych.

Ogólnie zwróciłbym uwagę na dobrą atmosferę pracy w Komisji, ale też w kontaktach z władzami polskimi. White żegnając się z Warszawa, na ręce Sztolcmana składał podziękowania za „pomoc, współpracę i gościnność”70. Sztolcman wspominając bliską współpracę z White’em i Gauthierem pisał natomiast:

To zaufanie, pomoc fachowa, a często i poparcie moralne, jakie od Przedstawicieli Ligi Narodów stale doświadczałem, były dla mnie bodźcem do pracy i dopomogły mi niezmiernie w osiagnięciu celu, do którego dążyliśmy. [...] Gdyby nie pomoc Ligi Narodów, zawsze śpieszna, życzliwa i skuteczna, zawsze oparta na głębokim zrozumieniu istotnego stanu rzeczy, na wiedzy i doświadczeniu, to niewatpliwie pomimo niesłychanych wysiłków ze strony Państwa Polskiego, walka z epidemiami nie dałaby tych dodatnich, a zwłaszcza tych bardziej trwałych wyników, jakie udało się osiagnąćc ${ }^{71}$.

Sztolcman wskazał na „wielkie inwestycje sanitarne”, gdzie „pomoc Ligi Narodów stała się najbardziej doniosłą i celowa" ${ }^{2}$.

Bardziej wyważoną od Sztolcmana ocenę zaprezentował szef warszawskiego biura Komisji White. Z jednej strony miał świadomość, że na tle ogromu pracy wykonanej przez władze polskie było to niewiele. Z drugiej strony uważał, że mimo wszystko Komisja pozostawiała po sobie konkretny dorobek, bo szpitale wzniesione na Kresach Wschodnich miały służyć mieszkańcom w kolejnych latach $^{73}$. Komisja Epidemiologiczna Ligi Narodów stopniowo kładła nacisk na stałe inwestycje sanitarne. Warunkiem było poniesienie części kosztów, w tym przeznaczenie terenu pod zabudowę przez samorządy. W efekcie rozpoczęto budowę 28 zakładów kapielowo-dezynfekcyjnych, głównie na Kresach, ale też na terenie dawnej Galicji i Kongresówki. Warto jeszcze przytoczyć opinię na temat współpracy Komisji z władzami polskimi, sformułowaną przez ministra Chodźkę:

Przyjmować pomoc od kogoś jest rzeczą nieraz bardzo przykra, ale zależy to niezmiernie wiele od sposobu, w jaki się ją okazuje. Komisja tak była dobrana, że współpraca pozostawiła organom polskim tylko miłe i dobre wrażenia. Autonomię polskich władz wykonawczych uszanowano w całej pełni, nie uzależniano nigdy dostarczenia jakichś środków od zmiany kierunku pracy władz polskich, a kontrolę sobie zastrzeżona starała się Komisja wykonywać w sposób jak najbardziej miły i ujmujący ${ }^{74}$.

\footnotetext{
${ }^{70}$ Ibidem, R823, Pismo Normana White'a do Sztolcmana, Genewa, 2.01.1924.

${ }^{71}$ Ibidem, Pismo Sztolcmana do Ludwika Rajchmana, Warszawa, 19.10.1923.

${ }^{72}$ Ibidem.

${ }^{73}$ Ibidem, Pismo Normana White'a do Sztolcmana, Genewa, 2.01.1924.

74 „Przegląd Epidemiologiczny” 1922, t. I, z. 7 dodatkowy, s. 816.
} 
Na koniec należy podkreślić osobisty wkład Rajchmana w kształtowanie długofalowego programu ochrony zdrowia, jaki miał być realizowany przez Ligę Narodów. Cytowana wcześniej korespondencja Birencwajga z Rajchmanem świadczy nie tylko o ich wzajemnej sympatii, ale o (potwierdzonych przez inne źródła) zdolnościach tego drugiego do nawiązywania kontaktów, zdobywania zaufania i zgodnej współpracy ${ }^{75}$. Na pewno Rajchman był dużym autorytetem dla wszystkich - urzędników w Genewie, współpracowników z Komisji w Warszawie, także dla urzędników sowieckich. Zawsze liczono się z jego zdaniem, pytano o opinię, był lubiany. Birencwajg w jednym z listów, raczej bez sztucznie brzmiącej kurtuazji, wspominając o sytuacji w Państwowym Zakładzie Higieny w Warszawie, którym przecież Rajchman kierował, podkreślił: „Na wiadomość o rychłym przyjeździe P[ana] Doktora do W[arszawy] wszystkim się oczy rozjaśniły"76. Minister Chodźko w raporcie z działalności NNK, opublikowanym w „Przeglądzie Epidemiologicznym”, zaznaczył: „Zarówno dla całej sprawy wprowadzenia akcji przeciwepidemicznej w Polsce na tory międzynarodowe, jak też dla ułożenia w sposób wysoce lojalny stosunku pomocy zagranicznej dla władz polskich, zasługi D-ra Rajchmana sa nadzwyczaj wybitne"77. Bardzo pozytywną opinię wygłosił po latach Walters: „W kolejnych latach aktywny i błyskotliwy umysł Rajchmana oddał nadzwyczajne usługi Lidze"78. Miał świetne opinie od właściwie wszystkich organizacji, z którymi współpracowal ${ }^{79}$. Poza tym, jak podkreśliła Marta Balińska, Drummond tą nominacją dał też wyraz swoim dążeniom, by nadać Sekretariatowi możliwie międzynarodowy charakter $^{80}$. Bardzo ciepło wspomniał Rajchmana jeden z prekursorów integracji europejskiej, Jean Monnet:

Chciałbym zatrzymać się chwilę na[d] życiem i osobowością tego nadzwyczajnego człowieka, którego przyjaźń była dla mnie tak cenna. U niewielu ludzi dostrzegłem tyle poczucia uniwersalności ile u Rajchmana. Z jednego kontynentu na drugi,

${ }^{75}$ Nie zachowały się co prawda listy Rajchmana, ale sądząc po stylu wypowiedzi Birencwajga, dobrze się rozumieli i choć wszystkie listy zostały przez Rajchmana oddane do akt Komisji, to trudno je uznać za formalne sprawozdania lub raporty pisane przez podwładnego. Birencwajga cenili też brytyjscy koledzy. Kiedy odchodził z Komisji, gdy redukowano personel ze względów oszczędnościowych w kwietniu 1923 r., Johnston-Watson poprosił Rajchmana o specjalny list z referencjami dla niego: „Zrobiłbym to sam z przyjemnościa, ale myślę, że jego praca dla Kom[isji] Ep[idemiologicznej] zasługuje na coś więcej, niż moja pokorną wdzięczność!”. Biblioteka Narodów Zjednoczonych (Genewa), Archiwum Ligi Narodów, R822, Pismo Johnstona-Watsona do Ludwika Rajchmana, Warszawa, 18.04.1923.

${ }^{76}$ Ibidem, Pismo Michała Birencwajga do Ludwika Rajchmana, Warszawa, 20.05.1922.

77 „Przegląd Epidemiologiczny” 1922, t. I, z. 7 dodatkowy, s. 812-813.

${ }^{78}$ F.P. Walters, op. cit., s. 101.

${ }^{79}$ M.A. Balińska, Ludwik Rajchman..., s. 89-90.

${ }^{80}$ Ibidem, s. 90. 
poprzez granice i reżimy, utrzymywał ludzkie, pełne oddania kontakty, które czyniły z niego przyjaciela najbardziej bezinteresownego i zarazem najskuteczniejszego. [...] Podziwiałem jego aktywność i rezultaty, owoce jego organizacyjnego geniuszu i poświęcenia ${ }^{81}$.

\section{Streszczenie}

Komisja Epidemiologiczna, która zaczęła działać w Polsce, jest przykładem swego rodzaju poligonu doświadczalnego dla nowo powstałej Ligi Narodów w kwestii ochrony zdrowia na skalę europejska. Jej działalność wiązała się przede wszystkim z planem zorganizowania na ziemiach polskich kordonu sanitarnego chroniącego Europę Zachodnią przed chorobami zakaźnymi. Jednak w dokumentach Komisji widać, jak dużą wagę przywiązywano do rozszerzenia jej aktywności na inne kraje, głównie Rosję i jakie znaczenie słusznie przypisywano współpracy między państwami w zakresie wzajemnego informowania o zagrożeniach. Komisja nakłaniała do współpracy przedstawicieli państw, które nie weszły do Ligi Narodów, promując ujednolicone metody zbierania i opracowywania informacji oraz przekonujacc o potrzebie koordynowania działań prozdrowotnych. Zgodnie układały się kontakty Komisji z władzami polskimi. Obie strony podkreślały, że współpraca przebiegała w dobrej atmosferze. Trzeba zauważyć, że wkład finansowy ze strony Ligi Narodów był stosunkowo niewielki. Jednocześnie Komisja pozostawiła po sobie konkretny dorobek, bo szpitale wzniesione z jej środków w Polsce miały służyć mieszkańcom w kolejnych latach. W cytowanej dokumentacji widać osobisty wkład Ludwika Rajchmana w kształtowanie długofalowego programu ochrony zdrowia, jaki miał być realizowany przez Ligę Narodów. Nawet w korespondencji (pół)urzędowej widać sympatię, jaką się cieszył, zdolności do nawiązywania kontaktów, zdobywania zaufania i zgodnej współpracy.

\section{The Operation of the League of Nations' Epidemic Commission in Warsaw 1921-1924}

The Epidemic Commission, which began operating in Poland, is an example of a testing ground for the newly established League of Nations in the field of health protection on a European scale. Its activity was related mainly to the plan to organise a sanitary cordon on the Polish territory to protect Western Europe from infectious diseases. However, the Commission's documents indicate how much importance was attached to extending its activities to other countries, mainly Russia, and how significant it was for the League of Nations cooperation between states in mutual information on dangers. The Commission encouraged representatives of the countries that had not joined the League of Nations to cooperate, promoting unified methods of gathering and processing information and arguing for the need to coordinate health-promoting activities. The contacts between the Commission and the Polish authorities were harmonious. Both sides emphasised that the cooperation was conducted in a good atmosphere. It should be noted that the financial contribution of the League of Nations was relatively small. The Commission, however, left behind a tangible legacy, as the hospitals built with its funds in Poland were to serve Polish people in coming years. The cited documents reveal Ludwik Rajchman's personal contribution to shaping the long-term health care programme to be implemented by the League of Nations. Even in (semi-)official correspondence, one can see the sympathy he enjoyed, his ability to make contacts, gain trust, and cooperate in harmony and concord.

${ }^{81}$ J. Monnet, Wspomnienia, tłum. i przypisami opatrzył W. Kuczyński, Warszawa 2015, s. $117-118$. 


\section{Bibliografia}

Allen A., Fantastyczne laboratorium doktora Weigla. Lwowscy uczeni, tyfus i walka z Niemcami, tłum. B. Gadomska, Wołowiec 2016.

Balcerak W., Liga Nadziei. Z dziejów Ligi Narodów, Warszawa 2010.

Balińska M.A., Assistance and not mere relief: the Epidemic Commission of the League of Nations, 1920-1923, w: International Health Organisations and Movements, 1918-1939, red. P. Weindling, Cambridge 1995, s. 81-108.

Balińska M.A., Ludwik Rajchman. Życie w służbie ludzkości, tłum. M. Braunstein, M. Krasicki, Warszawa 2012.

Dubin M.D., The League of Nations Health Organisation, w: International Health Organisations and Movements, 1918-1939, red. P. Weindling, Cambridge 1995, s. 56-80.

League of Nations. Ten Years of World Cooperation, Geneva 1930.

Sierpowski S., Liga Narodów w latach 1919-1926, Wrocław 2005.

Walters F.P., A History of the League of Nations, London 1952.

Weindling P., Epidemics and Genocide in Eastern Europe, 1890-1945, Oxford 2011.

Więckowska E., Kształtowanie się ochrony zdrowia, w: Dzieje medycyny w Polsce. Opracowania i szkice, t. II: Lata 1914-1944, red. W. Noszczyk, J. Supady, Warszawa 2015, s. 65-74.

Więckowska E., Walka z ostrymi chorobami zakaźnymi w Polsce w latach 1918-1924, Wrocław 1999.

Paweł Jaworski - prof. dr hab., Instytut Historyczny Uniwersytetu Wrocławskiego, historyk. Zajmuje się historią Skandynawii, stosunków polsko-skandynawskich w XX w., dziejami Europy Środkowej. E-mail: pawel.jaworski@uwr.edu.pl.

Pawel Jaworski - Prof. Dr. hab., employed at the Institute of History of the University of Wrocław, historian. He deals with the history of Scandinavia, Polish-Scandinavian relations in the 20th c., the history of Central Europe. E-mail: pawel.jaworski@uwr.edu.pl. 